Acta vet. scand. $1967,8,217-227$.

Institute for the Application of Nuclear Energy in Agriculture, Veterinary Medicine and Forestry, Zemun, Yugoslavia, and the Department of Physiology, Endocrinology and Bloodgrouping, Royal Veterinary and Agricultural College, Copenhagen, Denmark.

\title{
FREE AMINO ACIDS \\ IN THE BLOOD PLASMA OF NEWBORN PIGLETS BEFORE AND AFTER THE FIRST INTAKE OF COLOSTRUM*)
}

\author{
By \\ Margita Čuperlovic
}

It is well known that after a protein meal the content of free amino acids increases in the blood plasma. This increase is mainly proportional to the amino acid content of food proteins (Denton \& Elvehjem 1954, Guggenheim et al. 1960). In man, it has been found that after a high protein meal the increase of the concentrations of plasma amino acids is not entirely parallel to the relative amino acid composition of food proteins (Frame 1958). The greatest increase of plasma concentrations has been noted in valine, leucine and isoleucine. In addition, Stein et al. (1954) have found that the increase in amino acid concentration in blood plasma, when measured two hours after the intake of casein by adults, reflects to a certain degree the amino acid composition of casein. In pigs, an increased level of dietary protein is followed by higher plasma concentrations of glutamic acid, isoleucine, leucine, ornithine, threonine, tyrosine and valine. No significant effect of an increased food protein level was observed in plasma concentrations of aspartic acid, glycine, histidine,

*) This investigation was supported in part by Federal and Republic Fund for Coordination of Scientific Investigations, SFR Yugoslavia and by United States Department of Agriculture, USA, Grant no. PL 480. 
lysine, methionine, phenylalanine, proline and serine (Richardson et al. 1965).

In newborn animals, where the excretion of proteolytic enzymes is relatively small and where the microflora of the gastrointestinal tract is undeveloped, the influence of food proteins on free amino acid content in plasma is supposed to be more pronounced. The purpose of the present report is therefore to show, how the first intake of colostrum is reflected in the content of free amino acids in the plasma of newborn pigs.

\section{MATERIAL AND METHODS}

Six sows of the Swedish Landrace, each with 10 piglets, were taken for the experiment. Piglets weighing less than $0.96 \mathrm{~kg}$ were not included in the experiment. The average weight of the accepted piglets immediately after farrowing was $1.26 \mathrm{~kg}$, ranging from 0.96 to $1.98 \mathrm{~kg}$. The age of the sows ranged from 2 to 4 years.

The first blood sample was taken from all piglets immediately after farrowing. When farrowing had ended, the piglets were weighed and left with the sow for $1 \mathrm{hr}$. Then all animals were separated from the sow for 2 hrs. and weighed. After weighing a second blood sample was drawn. A colostrum sample was collected from each sow after an oxitocin injection.

The blood was taken both times from the V. jugularis and immediately transferred into heparinized tubes. In order to separate the plasma $5 \mathrm{ml}$ of blood was centrifuged immediately. The total plasma protein content was determined colorimetrically by means of the biuret reaction (De la Huerga et al. 1964). The plasma samples were subsequently examined electrophoretically by means of agar-gel electrophoresis and free electrophoresis on the Kern apparatus using the Labhart-Staube method.

One mi plasma samples taken simultaneously from all piglets of the same litter were pooled and prepared for amino acid analysis as described by Stein \& Moore (1954). The analyses were performed on the Spinco Beckman, Model 120 B automatic amino acid analyser.

The colostrum samples were hydrolyzed by the addition of $12 \mathrm{~N}-\mathrm{HCl}$ and heating for $22 \mathrm{hrs}$. at $110^{\circ} \mathrm{C}$. After hydrolysis the samples were filtrated and evaporated nearly to dryness. The samples were dissolved in citrate buffer, $\mathrm{pH} 2.2$, prior to analysis on the amino acid analyser. 


\section{RESULTS AND DISCUSSION}

All piglets were weighed before each blood collection. It may be seen from Table 1 that only minor weight changes had taken place in the course of $3 \mathrm{hrs}$. between two blood collections. In litter 3 and 4 the average weight after the second blood collection was higher than after the first sampling. The differences observed do not express the quantity of colostrum which has been taken up, due to the influence on the body weight by the excretion of urine and faeces. This also explains why litter 1 , in average, did not change weight at all and litter 2 was even lighter after the second sucking. In litter 5 , piglets were not weighed after the second sucking.

T a b l e 1. Body weight and total plasma protein content in newborn piglets before and after intake of colostrum.

\begin{tabular}{|c|c|c|c|c|c|c|c|}
\hline \multicolumn{2}{|c|}{ Litter number } & \multirow{2}{*}{$\begin{array}{r}1 \\
1.06 \\
\pm 0.15\end{array}$} & \multirow{2}{*}{$\begin{array}{r}2 \\
1.25 \\
\pm 0.25\end{array}$} & \multirow{2}{*}{$\begin{array}{r}3 \\
1.34 \\
\pm 0.32\end{array}$} & \multirow{2}{*}{$\begin{array}{r}4 \\
1.40 \\
\pm 0.35\end{array}$} & \multirow{2}{*}{$\begin{array}{r}5 \\
1.24 \\
\pm 0.09\end{array}$} & \multirow{2}{*}{$\begin{array}{r}6 \\
1.21 \\
\pm 0.13\end{array}$} \\
\hline $\begin{array}{l}\text { Body } \\
\text { weight }\end{array}$ & $\begin{array}{l}\text { Before } \\
\text { sucking }\end{array}$ & & & & & & \\
\hline$(\mathrm{kg})$ & $\begin{array}{l}\text { After } \\
\text { sucking }\end{array}$ & $\begin{array}{r}1.06 \\
\pm 0.21\end{array}$ & $\begin{array}{r}1.22 \\
\pm 0.25\end{array}$ & $\begin{array}{r}1.42 \\
\pm 0.35\end{array}$ & $\begin{array}{r}1.43 \\
\pm 0.29\end{array}$ & & $\begin{array}{r}1.23 \\
\pm 0.18\end{array}$ \\
\hline \multirow{2}{*}{$\begin{array}{l}\text { Plasma } \\
\text { proteins } \\
\quad(\mathrm{g} \%)\end{array}$} & $\begin{array}{l}\text { Before } \\
\text { sucking } \\
\end{array}$ & $\begin{array}{r}2.80 \\
\pm 0.05 \\
\end{array}$ & $\begin{array}{r}2.60 \\
\pm 0.07 \\
\end{array}$ & $\begin{array}{r}2.60 \\
\pm 0.18 \\
\end{array}$ & $\begin{array}{r}2.75 \\
\pm 0.25 \\
\end{array}$ & $\begin{array}{r}2.70 \\
\pm 0.26 \\
\end{array}$ & $\begin{array}{r}2.90 \\
\pm 0.15 \\
\end{array}$ \\
\hline & $\begin{array}{l}\text { After } \\
\text { sucking }\end{array}$ & $\begin{array}{r}3.70 \\
\pm 0.20\end{array}$ & $\begin{array}{r}3.15 \\
\pm 0.26\end{array}$ & $\begin{array}{r}3.05 \\
\pm 0.32\end{array}$ & $\begin{array}{r}3.00 \\
\pm 0.40\end{array}$ & $\begin{array}{r}3.25 \\
\pm 0.30\end{array}$ & $\begin{array}{r}3.97 \\
+0.21\end{array}$ \\
\hline
\end{tabular}

The total protein content in the blood plasma increased in all litters and in all animals after the first sucking. The quantities of total protein before and after the intake of colostrum are shown in the second part of Table 1 as average values for all piglets from the same litter.

The electrophoretic analysis of plasma proteins did not show any apparent qualitative differences in protein composition during the period examined. The electrophoretic differences observed in samples taken before and after uptake of colostrum were quantitative and could be ascribed to the increase in total content of plasma protein.

The gamma-globulin fraction was not observed in any of the electrophoregrams examined, and the concentrations of other fractions were not quantitatively established. 


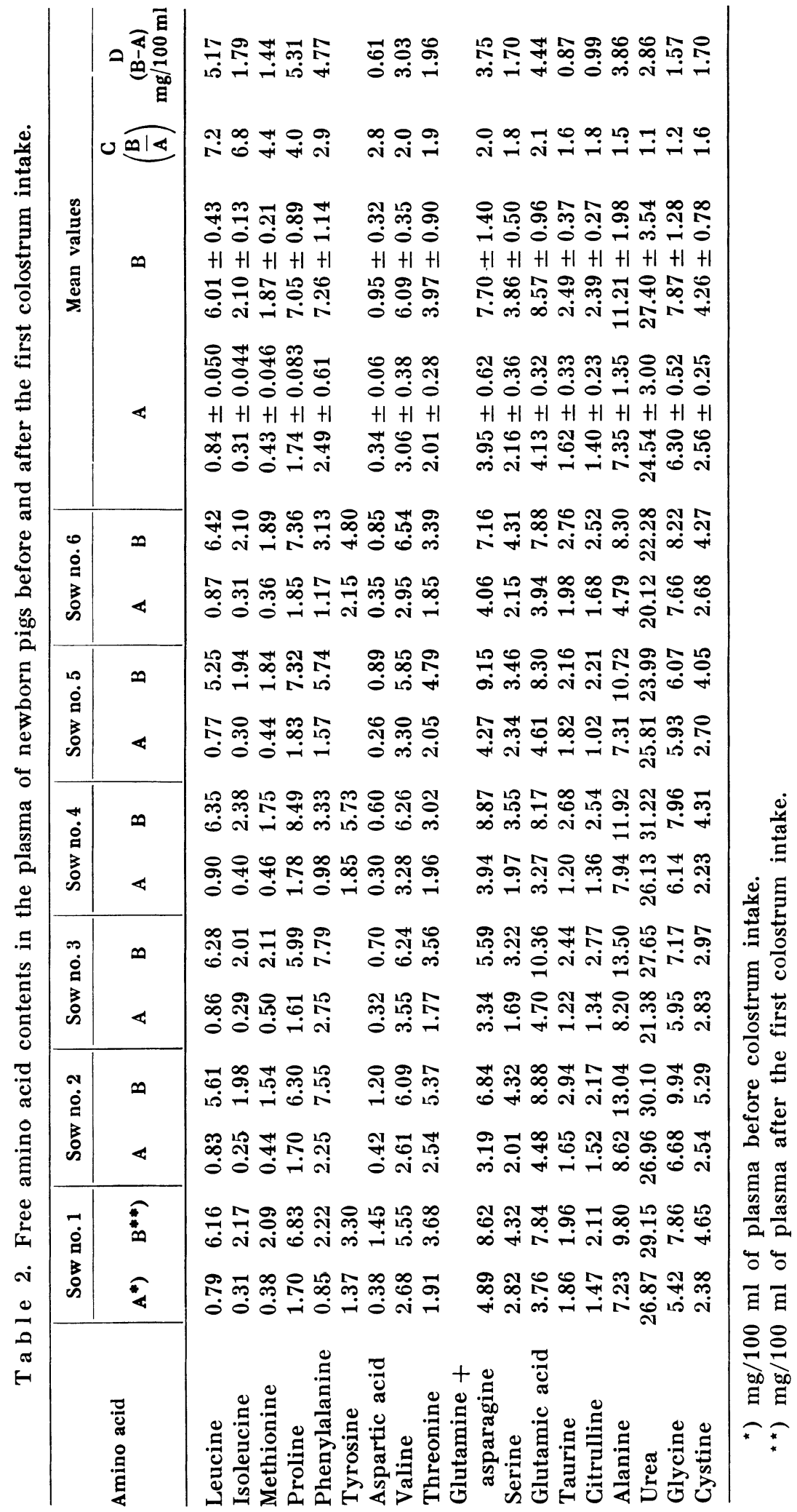




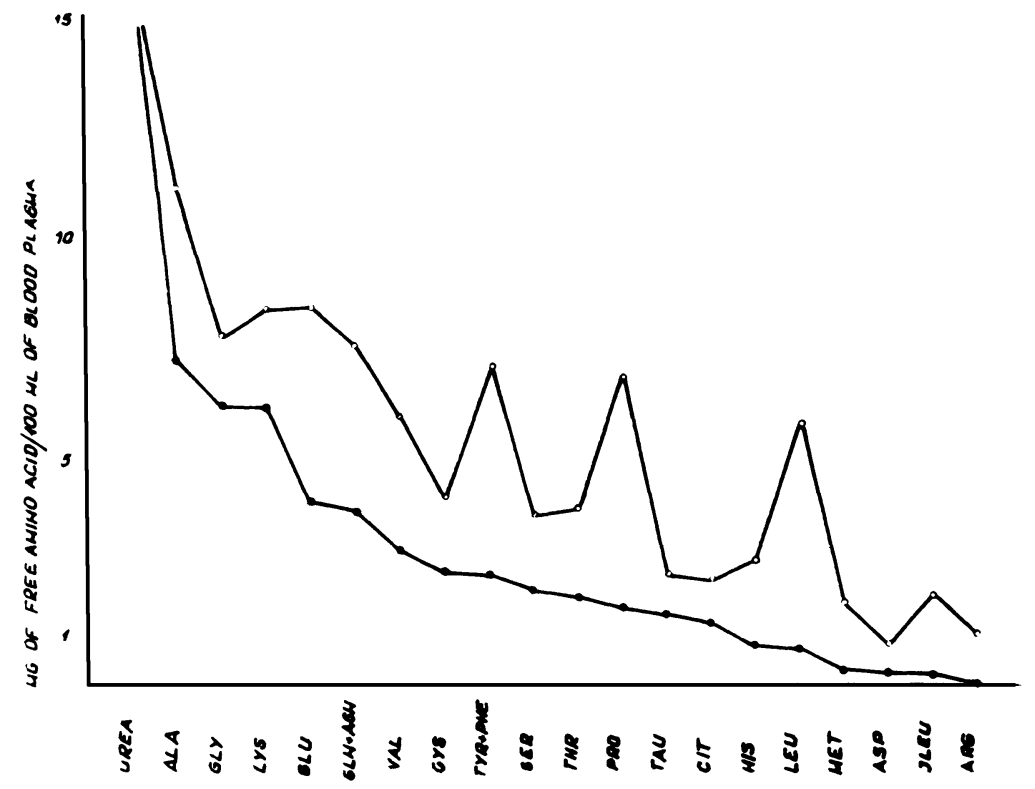

F ig u re 1. Free amino acid content in the plasma of newborn pigs before and after the first colostrum intake. - - - : before sucking, -o-: after sucking.

The effect of the first sucking on the free amino acid content in blood plasma of piglets was most pronounced.

Table 2 presents data which show the free amino acid content in plasma before and after sucking, expressed as $\mathrm{mg}$ per $100 \mathrm{ml}$ of plasma. Fig. 1 is the graphical illustration of these data. Each point on the graph represents the mean value for the concentration of one amino acid in all plasma samples, which have been collected at the same time. The free amino acid concentrations are here defined in terms of ion-exchange analysis, and some ninhydrin reacting compounds which are not true acids (taurine, glutamine, asparagine, urea) are included.

The quantities of all amino acids determined in plasma before sucking are given in column $A$ of Table 1 , and after sucking in column B. All mean values with corresponding standard deviations are given at the end of Table 1 .

The qualitative pattern of free amino acids in plasma was not changed after sucking, but the quantities of each amino acid were higher. The greatest absolute increase observed, expressed as the difference of amino acid concentrations before and after 
sucking (column D), was noted in proline, leucine, glutamic acid and alanine, respectively. If, however, relative increases are observed i.e. ratios between plasma amino acid concentrations before and after sucking (column $\mathrm{C}$ ), then the order of amino acids is changed to: leucine, isoleucine, methionine, proline. It is evident, in both cases, that the leucine and proline contents are significantly increased, while a proper impression of the increase of methionine can only be obtained when the relatively small content in the blood before sucking is taken into consideration.

In the blood taken after sucking the content of methionine was found to be 4.4 times greater than in the blood taken before sucking. With isoleucine the situation was similar, namely 6.8 times more after sucking than before. A higher relative effect has been noticed in leucine only, namely 7.2 times more after sucking.

It was not possible to separate amines (glutamine and asparagine) by the analytical technique applied. It is, however, known that glutamine represents $90 \%$ of their complete amount. The amine concentration has increased considerably after sucking, the increase being $3.75 \mathrm{mg} / 100 \mathrm{ml}$ of plasma, and even relatively, the concentration was two times higher after the second blood collection.

The increase of glutamic acid is considerable after sucking. In the second sample the increase was found to be $4.44 \mathrm{mg}$ per $100 \mathrm{ml}$ of plasma, which is $\mathbf{2 . 1}$ times more than in the first sample.

The smallest effect of the first sucking on plasma amino acid concentration was observed in the urea and glycine concentrations, especially if their relatively high concentration in blood before sucking is taken into consideration. There are 1.1 times more urea and 1.2 times more glycine after the second blood collection.

As mentioned earlier a colostrum sample was taken from all the sows (except from no. 2) and protein and amino acid concentrations were determined.

Table 3 and Fig. 2 show the results of these analyses. The mean value for the content of crude protein from 5 colostrums analysed is $164.24 \mathrm{~g} / \mathrm{l}$ with a rather high $\mathrm{s}$ of \pm 12.16 . The colostrum of sow no. 4 , in which the smallest quantity of protein was found, contained also the smallest quantity of amino acid, expressed in $\mathrm{g}$ per 1 of colostrum. If, however, the amino acid concentration is expressed in percentage of protein, no significant differences are noted in the colostrum of all sows investigated. 


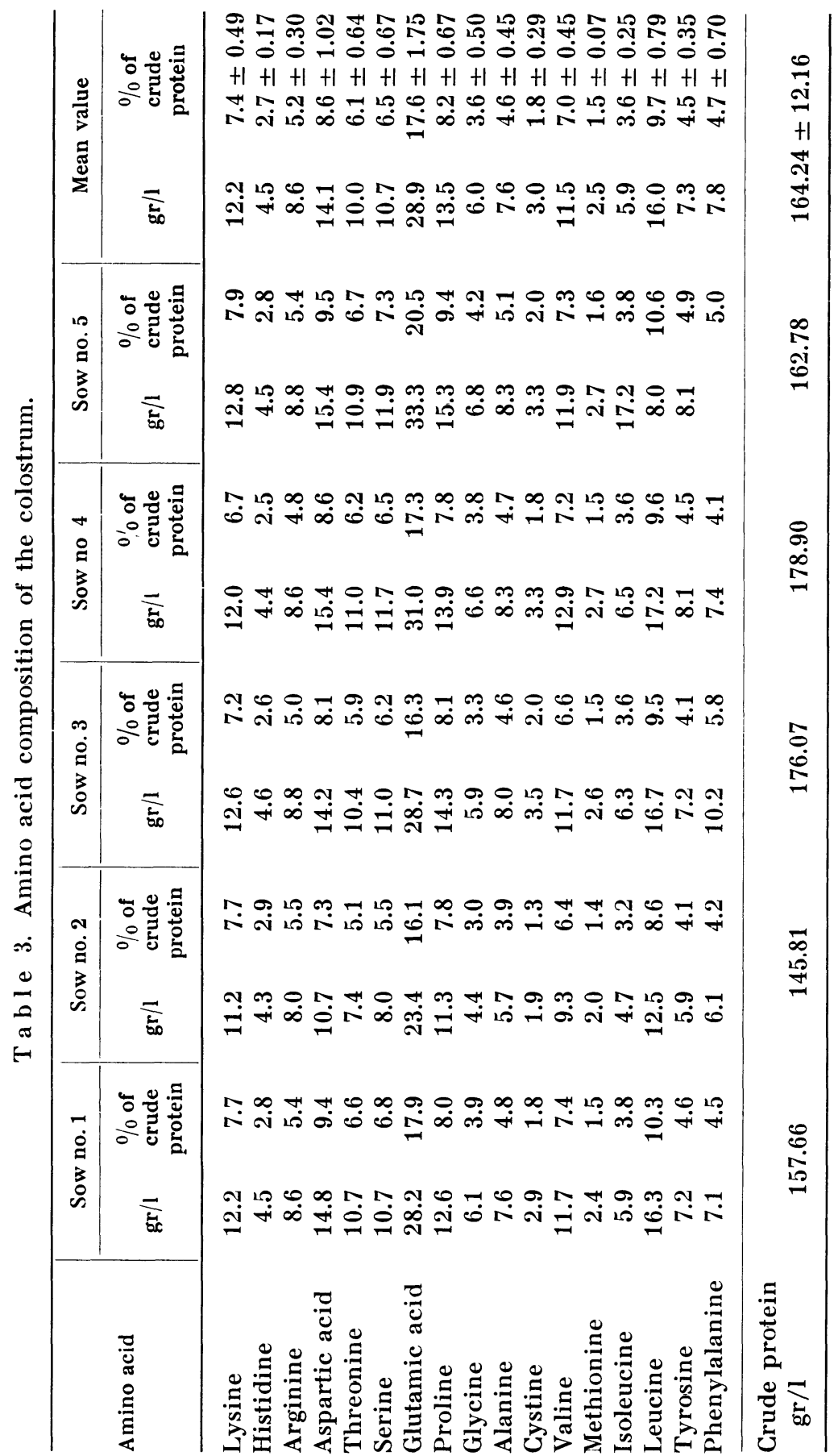




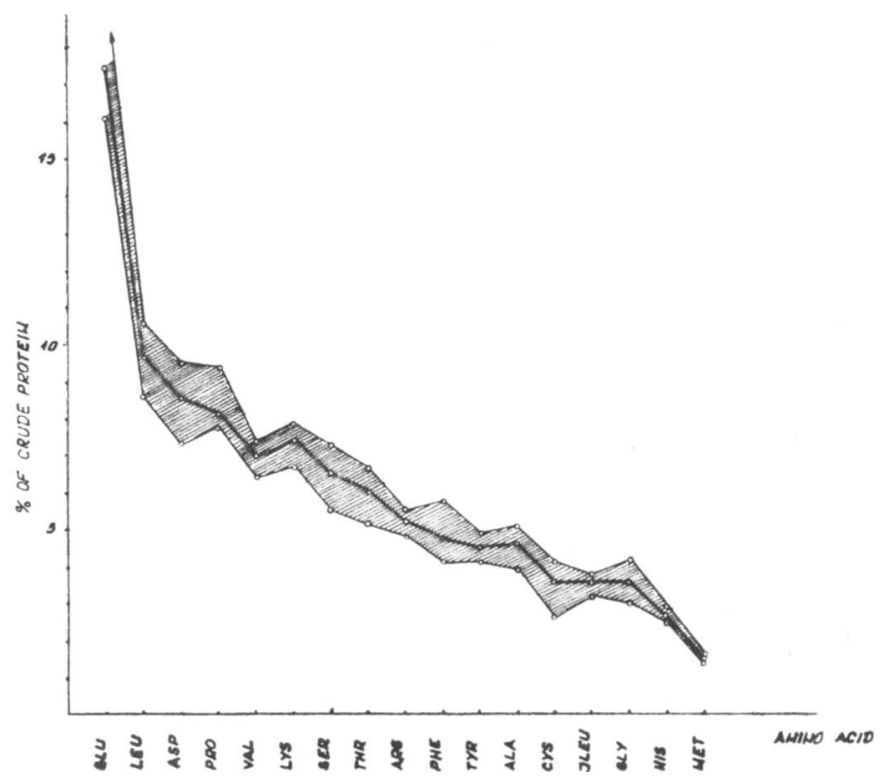

F i g u r e 2. Amino acid composition of the colostrum (in $\%$ of the crude protein).

The tryptophan concentration could not be determined in colostrum since this amino acid is destroyed in the course of hydrolysis. The concentration of glutamic and aspartic acid found is excessively high due to the conversion of amines into the corresponding acids with the liberation of ammonia.

In Fig. 3 the concentrations of amino acids in the colostrum $(\mathrm{g} / \mathrm{l})$ have been compared with the increase of the free amino acid concentrations in plasma $(\mathrm{mg} / 100 \mathrm{ml}$ of plasma) of the piglets after sucking. The amino acids which were not found in the hydrolysate of colostrum (citrulline, taurine, urea), were not taken into account. In some plasma samples it was impossible to separate tyrosine and phenylalanine. They were therefore observed together. During these experiments no attention was paid to the fact that amino acids from the colostrum immunoglobulins may contribute a little or not at all to the body amino acid pool. The amino acids with the highest concentration in colostrum (leucine, tyrosine-phenylalanine and proline) have caused the greatest increase of free amino acid concentration in plasma, which is clearly seen in Fig. 1. The increase of the alanine and histidine in plasma is also high, even though their concen- 


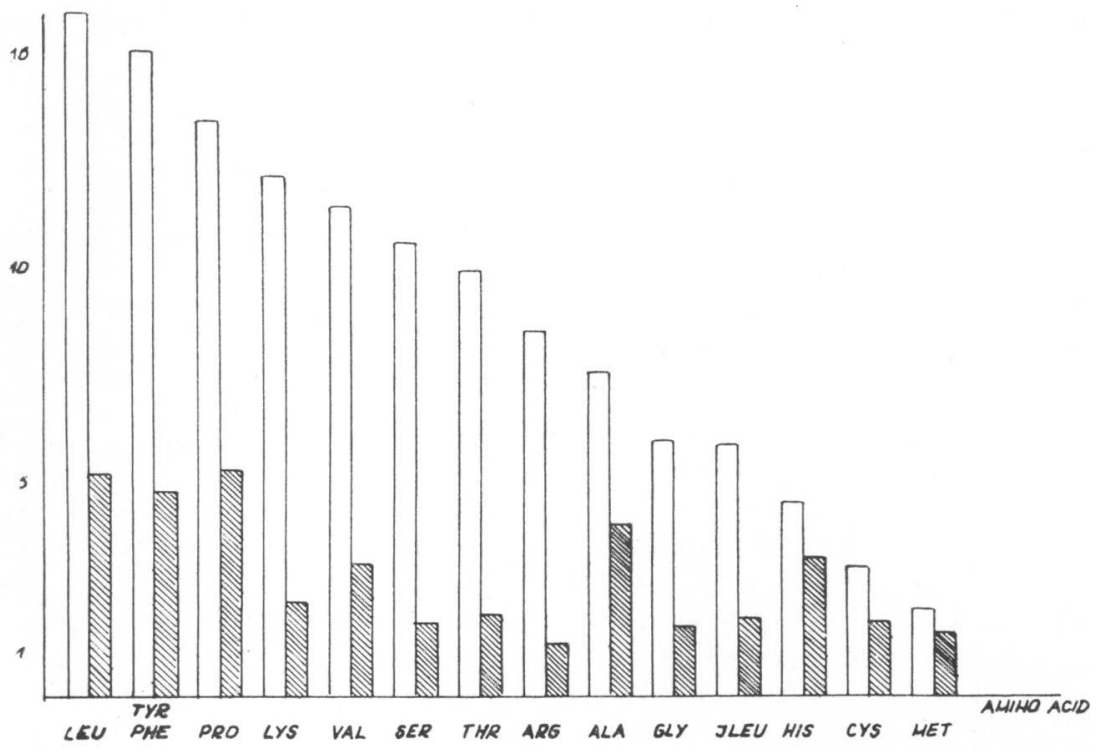

$\mathrm{Figure} 3$. Difference in the concentration of free amino acids in blood plasma before and after sucking (VIyvy) compared with the concentration of amino acids in the colostrum ( $\square, \mathrm{g} / \mathrm{l}$ of colostrum).

tration in the colostrum is considerably less. The colostrum is relatively poor in methionine, the concentration of this amino acid in the plasma is nevertheless 4.4 times higher after sucking than before. The cystine from the colostrum covers most likely a part of the need for methionine in piglets. If, however, the order of limiting amino acids in colostrum were determined, it is obvious that methionine should be put on the first place.

It is interesting to note that the increase of the lysine content in plasma is very low, even though the colostrum is rich in this amino acid. Ghadimi \& Pecora (1964) have found that in children the concentrations of lysine, taurine and threonine during the first week of life decrease, while during the second week they reach a level which is maintained during the entire childhood. This is in accordance with the relatively small increase of these amino acid concentrations after the first sucking in newborn piglets which has been found in these investigations. Fig. 1 shows that the increase of the glutamic acid and glutamine concentrations is considerable. This might be due to the fact that these amino acids appear in a large number of known catabolic pathways. 
A very small increase of the urea content indicates the predomination of anabolism over catabolism of amino acids in this early period of life.

\section{ACKNOWLEDGMENTS}

The author is indebted to Professor, dr. med. vet. Johs. Moustgaard (Royal Veterinary and Agricultural College, Copenhagen) for his initiative and helpful suggestions, and to Dr. D. Stošić (Institute for the Application of Nuclear Energy in Agriculture, Veterinary Medicine and Forestry, Zemun, Yugoslavia) for continuous help in the course of this work.

\section{REFERENCES}

Denton, A. E. \& C. A. Elvehjem: Availability of amino acids in vivo. J. biol. Chem. 1954, 206, 449_454.

Frame, E. G.: The levels of individual free amino acids in the plasma of normal man at various intervals after a high-protein meal. J. clin. Invest. 1958, 37, 1710-1723.

Ghadimi, H. \& P. Pecora: Plasma amino acids after birth. Pediatrics 1964, 34, 182-191.

Guggenheim, K., S. Halevy \& N. Friedman: Levels of lysine and methionine in portal blood of rats following protein feeding. Arch. Biochem. 1960, 91, 6-10.

Huerga, J. de la, G. W. Smetters \& J. C. Sherrick: Colorimetric determination of serum proteins: the biuret reaction. Serum proteins and the dysproteinemias, ed. F. S. Sunderman and F. W. Sunderman Jr., Pitman Med., London 1964, p. 52.

Richardson, L. R., F. Hale \& S. J. Ritchey: Effect of fasting and level of dietary protein on free amino acids in pig plasma. J. Animal Sci. 1965, 24, 368-372.

Stein, W. H. \& S. Moore: The free amino acids of human blood plasma. J. biol. Chem. 1954, 211, 915-926.

Stein, W. H., A. G. Bearn \& S. Moore: The amino acid content of the blood and urine in Wilson's disease. J. clin. Invest. 1954, 33, $410-419$.

\section{SUMMARY}

The first intake of colostrum changes to a great degree the quantitative composition of free plasma amino acids in newborn piglets.

A considerable increase of concentration has been observed especially with respect to those amino acids which are most abundant in colostrum (leucine, proline and tyrosine-phenylalanine). When the low plasma concentration prior to treatment with colostrum is considered, the plasma level of isoleucine and methionine after the first sucking was considerably increased in spite of the fact that the amount of methionine present in colostrum is relatively small. The increase in urea and glycine content was very small when compared with the high concentration before sucking. 
On basis of the present data it can be concluded that the quantitative changes in the plasma amino acid pool $2 \mathrm{hrs}$. after the intake of colostrum reflect only to a limited degree the amino acid composition of colostrum, in spite of the fact that in this early period of life colostrum is completely absorbed from the intestinal tract.

\section{ZUSAMMENFASSUNG \\ Der Gehalt an freien Aminosäuren im Blutplasma von neugeborenen Ferkeln bevor und nach der Aufnahme von Colostrum.}

Das erste Einführen von Colostrum hatte eine bedeutende Veränderung in der quantitativen Zusammensetzung der freien Aminosäuren im Plasma bei neugeborenen Ferkeln zur Folge.

Es wurde ein starkes Anwachsen der Konzentration derjenigen Aminosäuren, welche im Colostrum am reichlichsten vertreten sind, festgestellt (Leuzin, Prolin, Tyrosin und Phenylalanin zusammengenommen). In Verhältnis zur niedrigen anfänglichen Konzentration, jedoch, war der Gehalt an Isoleuzin und Methionin ebenfalls erheblich angewachsen, obwohl die letztgenannte Aminosäure in dem Colostrum relativ gering vertreten ist. Das Anwachsen des Gehalts von Urea und Glycin war sehr bescheiden im Verhältnis zur anfänglichen hohen Konzentration.

Auf Grund dieser Ergebnisse kann konkludiert werden, dass die quantitative Änderungen des Aminosäuregehalts des Plasmas zwei Stunden nach dem Einführen von Colostrum nur im begrenzten Ausmass seine Aminosäurenzusammensetzung widerspiegelt, obwohl das Colostrum in diesem frühen Lebensabschnitt vollständig absorbiert wird.

\section{SAMMENDRAG}

Indholdet af frie aminosyrer $i$ blodplasma fra nyfødte grise før og efter optagelse af kolostrum.

Den første optagelse af kolostrum ændrer i udstrakt grad den kvantitative sammensætning af de frie plasmaaminosyrer hos nyf $\varnothing$ dte grise.

En betydelig stigning i koncentrationen er især blevet konstateret af de aminosyrer, som er til stede i størst mængde i kolostrum (leucin, prolin og tyrosin-fenylalanin). Hvis man tager den lave plasmakoncentration $f \varnothing r$ behandling med kolostrum i betragtning, var plasmaindholdet af isoleucin og methionin efter optagelse af kolostrum betydeligt forøget på trods af, at methioninkoncentrationen i kolostrum er relativt lav. Stigningen i urinstof og glycinindholdet var meget lille sammenlignet med den h $\varnothing j e$ koncentration f $\varnothing \mathrm{r}$ optagelse af kolostrum.

På grundlag af de fundne data kan det konkluderes, at de kvantitative ændringer, man finder i plasmas aminosyresammensætning to timer efter optagelse af kolostrum, kun i begrænset grad genspejler kolostrums aminosyresammensætning, selvom kolostrum på dette tidlige tidspunkt efter partus absorberes fuldstændigt fra tarmkanalen.

(Received March 15, 1967). 